\title{
Size-density strategy displayed by Diadema africanum linked with the stability of urchin-barrens in the Canary Islands
}

\author{
NANCY CABANILLAS-TERÁN ${ }^{1}$, JOSÉ A. MARTÍN ${ }^{2}$, RUBER RODRÍGUEZ-BARRERAS ${ }^{3}$ AND ÁNGEL LUQUE ${ }^{2}$ \\ ${ }^{1}$ Laboratory of Marine Resources, Central Department of Research, Universidad Laica Eloy Alfaro de Manabí, Ciudadela \\ Universitaria, Vía a San Mateo, Manta, Manabí, Ecuador, EC130802, ${ }^{2}$ Department of Biology, Marine Sciences Faculty, University of \\ Las Palmas de Gran Canaria, 35017 Las Palmas de G.C., Canary Islands, Spain, ${ }^{3}$ Department of Biology, University of Puerto Rico, \\ Río Piedras. PO Box 23360, San Juan o0931-3360, Puerto Rico
}

\begin{abstract}
The sea urchin Diadema africanum is considered a key herbivore in sublittoral ecosystems of the Canary Islands. Spatial and temporal variability in population structure was carried out at Gran Canaria. We performed a morphometric and population density analysis during 2005, 2006 and 2007 at four sites in zones of Gran Canaria. The study considered a vertical gradient (5, 10 and $20 \mathrm{~m}$ depth) during both seasons, the cold season (February and March) and the warm season (October and November). The sea urchin D. africanum in Gran Canaria exhibited an overall density of $7.59 \pm 2.92$ urchin $\mathrm{m}^{-2}$. A two-way ANOVA evidenced spatial differences in mean abundance of the species, while seasonality was not relevant. The vertical analysis of the abundance of $\mathrm{D}$. africanum showed differences, the smaller sizes appeared at greater depths. The Aristotle's lantern width decreased in a vertical gradient, being remarkable between 10 and $20 \mathrm{~m}$. Findings of uniformity in size over time, a stable range of high densities and the lack of a relationship between the size of the sea urchins and the season reveals that the density-size strategy displayed by D. africanum which explains in turns the high stability of the urchin barrens, which, once developed, remain as areas of permanent desertification in subtidal depths throughout the Canary Archipelago.
\end{abstract}

Keywords: Diadema africanum, urchin barren, morphometry, abundance, Canary Islands

Submitted 6 June 2014; accepted 26 July 2014

\section{INTRDDUCTION}

Echinoderms have been called a 'boom - bust' phylum because of the large fluctuations of some species (Uthicke et al., 2009). There are many factors involved in the regulation of the structure of urchin population; where predation, recruitment, pollution, diseases, large-scale oceanographic events, food supplies, niche variability are some of them (Hyman, 1955; Dayton et al., 1984; Hughes, 1994; Sala \& Zabala, 1996; Sala \& Ballesteros, 1997; 2007; Lessios, 2013; García-Sanz et al., 2014). Hence, the ecological processes triggering these population explosions cannot be easily determined (Lessios et al. (2001); Hernández et al., 2008; Lessios, 2013). Expansion and crashes are more common than was usually thought. Overpopulation of sea urchins may generate extensive areas devoid of macroalgae (Lessios, 2013) called 'urchin barren'.

The presence of barrens has been extensively documented in the coastal zones of temperate environments and in subtropical and tropical regions (Sammarco, 1982; McClanahan \& Curtis, 1991; McClanahan, 1994; Alves et al., 2001; Brito et al., 2004; Tuya et al., 2005; Clemente et al., 2010; Lessios, 2013; García-Sanz et al., 2014). The development of barrens has been reported on rocky substrates of the Macaronesian islands,

Corresponding author:

N. Cabanillas-Terán

Emails: nanchamex@gmail.com/nancy.cabanillas@uleam.edu.ec without associated anthropogenic factors (Lawrence, 1975). However, higher densities of the sea urchins have been linked with overfishing and areas protected from high wave action (Bortone et al., 1991; McClanahan et al., 1996; Tuya et al., 2004a, 2005, 2007). Barrens are considered undesirable due to the negative impact on fisheries productivity (Clemente et al., 2010). Several studies have evaluated the role of Diadema africanum in subtidal coastal ecosystems, because it has become the most voracious consumer of the sublittoral vegetation in the

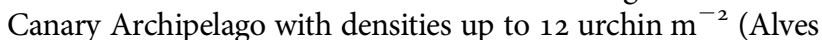
et al., 2003; Brito et al., 2004; Hernández et al., 2008; Clemente et al., 2010).

The long-spined sea urchin Diadema africanum (Rodríguez et al., 2013) is considered one of the most well known echinoid because of its important role as a benthic grazer in the Eastern Atlantic (Randall et al., 1964; Tuya et al., 2005; Lessios, 2013). The spatial distribution of Diadema has been linked to a variety of factors, including predation (Dayton et al., 1984; Sala \& Ballesteros, 1997), settlement and recruitment (Young \& Chia, 1982), availability of trophic resources (Menge, 1992) and competitive interactions (Hagen \& Mann, 1992). Changes in density may influence changes in the dimensions of some morphological structures of sea urchins, particularly the Aristotle's lantern (Garrido, 2003). This pentagonal structure forms an efficient scraping tool to acquire food, and its analysis provides important information about food limitation or plastic resource allocation (Ebert, 1980; Levitan, 1991). 
Therefore, the main objectives of this study were to: (1) determine the current population density of D. africanum; and (2) compare differences in the Aristotle's lantern across different space, time and vertical conditions.

\section{MATERIALS AND METHODS}

\section{Study area}

Surveys were conducted during 2005, 2006 and 2007 in four different areas on the island of Gran Canaria in the Canary Islands (Figure 1). The sites were La Catedral (LC: $28^{\circ} 10^{\prime} 57^{\prime \prime} \mathrm{N} 15^{\circ} 24^{\prime} 11^{\prime \prime} \mathrm{W}$ ), Sardina del Norte (SAR: $28^{\circ} 08^{\prime} 56^{\prime \prime} \mathrm{N} 15^{\circ} 42^{\prime} 02^{\prime \prime} \mathrm{W}$ ), Risco Verde (RV: $27^{\circ} 51^{\prime} 24^{\prime \prime} \mathrm{N}$ $15^{\circ} 23^{\prime} 9^{\prime \prime} \mathrm{W}$ ) and Puerto Rico (PR: $27^{\circ} 47^{\prime} 47^{\prime \prime} \mathrm{N} 15^{\circ} 43^{\prime} 59^{\prime \prime} \mathrm{W}$ ). Gran Canaria Island is nearly a round island with different environmental characteristics at the four sampling sites. LC and SAR are located far from urban areas, and are under the influence of north-east winds. Both sites have deep waters and are characterized by extensive rocky substrates. $\mathrm{RV}$ is a shallow water area on the east side of the island, protected from the wind, has a sandy substrate below $15 \mathrm{~m}$ and is adjacent to an urban centre. The fourth site, PR, is located to the south-west and is shallow, with a mixed substrate of rocks, gravel and sand below $10 \mathrm{~m}$ depth.

LC and SAR are colonized by sea urchins and exhibit no erect algae, but there are some encrusting red algae; whereas $\mathrm{RV}$ and PR are characterized by erect algae, predominantly of the genera Padina, Dictyota and Stypocaulon spp. (see Cabanillas-Terán, 2009 for more details). Censuses were conducted at three different depth ranges according to the specific topography of each site. Ten metres was the common depth for all sites (Table 1). Samples were taken in two seasons: warm (October-November) and cold (March-April), according to the time when the water exhibits its maximum $\left(23-24^{\circ} \mathrm{C}\right)$ and minimum $\left(17-18^{\circ} \mathrm{C}\right)$ peaks of temperature (Hernández et al., 2011).

\section{Survey methodology and population structure}

Mean density was estimated using a belt-transect methodology (Vanderklift \& Kendrick, 2004). At each site, eight random transects of $5 \mathrm{~m}^{2}$ were placed parallel to the shoreline
Table 1. Sampling depths for the four sites in Gran Canaria.

\begin{tabular}{llll}
\hline Sites & Depth 1 & Depth 2 & Depth 3 \\
\hline Risco Verde & $5 \mathrm{~m}$ & $10 \mathrm{~m}$ & - \\
Puerto Rico & $5 \mathrm{~m}$ & $10 \mathrm{~m}$ & - \\
La Catedral & - & $10 \mathrm{~m}$ & $20 \mathrm{~m}$ \\
Sardina del Norte & - & $10 \mathrm{~m}$ & $20 \mathrm{~m}$ \\
\hline
\end{tabular}

and separated $10 \mathrm{~m}$ from each other. All crevices and small holes were carefully inspected to avoid missing any individuals. Censuses were performed in 2005, 2006 and 2007 at each of the sampling sites in both the cold and warm seasons at different depths (Table 1). A total of 792 Diadema africanum were collected randomly across all sites for morphometric analysis during cold and warm seasons of 2005,2006 and the cold season of 2007 ( 25 individuals by site by depth). Individuals were collected randomly, brought to the laboratory, labelled and frozen for later analyses. Once in the laboratory, the Aristotle's lantern diameters were measured (caliper error: $0.05 \mathrm{~mm}$ ). Depth range in Table 1 was established according to the presence of D. africanum at these depths. We divided individuals in four size-classes following Tuya et al. (2004a, b): class 1: $1.5-3.5 \mathrm{~cm}$; class $2: 3.5-5.4 \mathrm{~cm}$; class $3: 5.5-7.4 \mathrm{~cm}$; and class $4: 7.5-10 \mathrm{~cm}$.

\section{Statistical analysis}

The Kolmogorov-Smirnov and Levene tests were run to test normality and homogeneity of variance for all biometric parameters (Zar, 2010). We ran a two-way analysis of variance (ANOVA) to test spatial and temporal differences in mean abundance and $(10 \mathrm{~m})$ mean size. This model incorporates time as the fixed and site as the random factor. In addition, we ran different one-way ANOVAs to determine potential differences in depth at each site of mean density, but also differences in depth and among sites for the Aristotle's lantern width. Multiple post-hoc Tukey's HSD analyses were run when ANOVAs were significant to identify specific subsets. Furthermore, we ran the parametric Pearson correlation among mean density of $D$. africanum and depth. All statistical

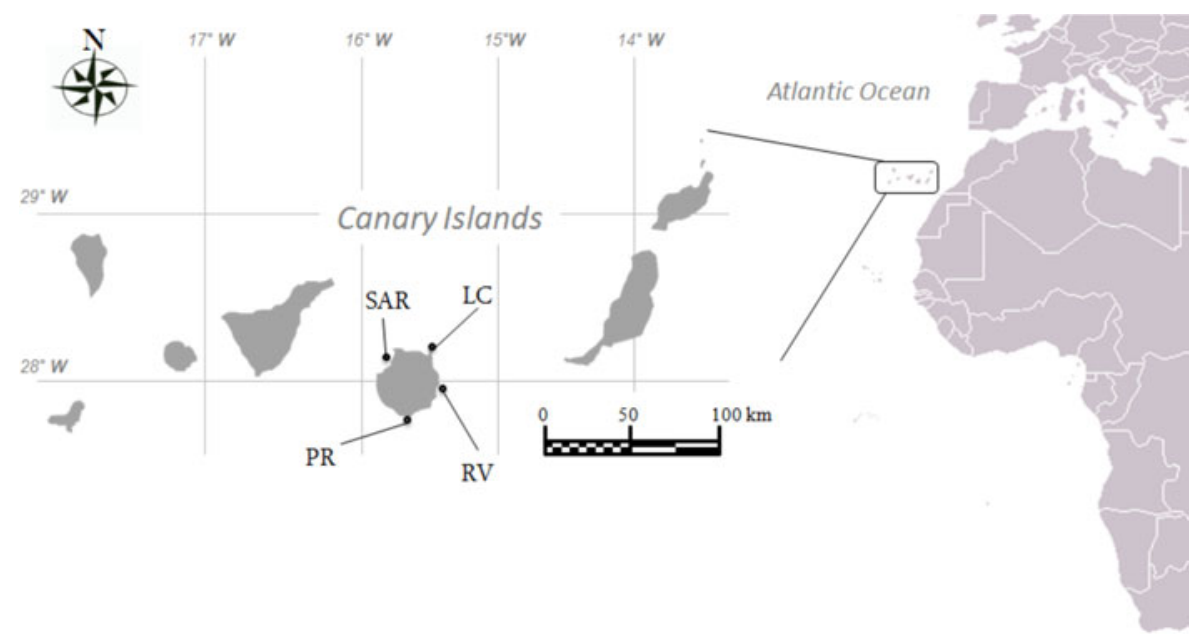

Fig. 1. Study area and sampling sites in Gran Canaria: Sardina (SAR); PR (Puerto Rico); Risco Verde (RV); La Catedral (LC). 
Table 2. A two-way analysis of variance on the abundances, and sizes of the sea urchin Diadema africanum at four sites of Gran Canaria. SS, sum of squares; MS, mean of squares.

\begin{tabular}{|c|c|c|c|c|c|c|}
\hline & \multicolumn{3}{|c|}{ Mean density* } & \multicolumn{3}{|c|}{ Mean size* } \\
\hline & df & $F$ & $P$ & df & $F$ & $P$ \\
\hline Time $(t)$ & 5 & 1.768 & 0.092 & 4 & 16.481 & $<0.001$ \\
\hline Site $(s)$ & 7 & 35.18 & $<0.001$ & 3 & 147.837 & $<0.001$ \\
\hline$S \times T$ & 17 & $\begin{array}{l}3.306 \\
\text { SS }\end{array}$ & $\begin{array}{l}<0.001 \\
\text { MS }\end{array}$ & 11 & $\begin{array}{l}18.198 \\
\text { SS }\end{array}$ & $\begin{array}{l}<0.001 \\
\text { MS }\end{array}$ \\
\hline Residuals & 355 & 3758.2 & 10.59 & 415 & 196.562 & 0.474 \\
\hline
\end{tabular}

*, comparisons were run only for $10 \mathrm{~m}$ data (the only common depth among sites).

analyses were performed in the free-license statistical software R-3.0.1 with a $P$ value of 0.05 (R Core Team, 2013).

\section{RESULTS}

The sea urchin D. africanum exhibited an overall density of $7.59 \pm 2.92$ (mean \pm standard deviation) urchin $\mathrm{m}^{-2}$ at Gran Canaria. The overall abundance varied from $2.09 \pm$ 1.42 urchin $\mathrm{m}^{-2}$ (PR) to $10.12 \pm 3.17$ urchin $\mathrm{m}^{-2}$ (SAR). Seasonal highest density of $D$. africanum was recorded at $\mathrm{RV}$ during the cold season of 2005 at $5 \mathrm{~m}(12.98 \pm$ 4.47 urchin $\mathrm{m}^{-2}$ ), while $\mathrm{PR}$ displayed the lowest density during the cold season in the same depth and year ( $0.75 \pm$ 0.45 urchin $\mathrm{m}^{-2}$ ) (Figure 2). A two-way ANOVA found spatial differences in mean abundance of the species, while seasonality was not relevant (Table 2). The post-hoc analysis determined that the most important differences in abundances occurred between RV with respect to LC/PR $(P<$ 0.001), and between PR/SAR $(P<0.001)$. On the other hand, the abundance across a vertical gradient (depth) exhibited higher densities at $20 \mathrm{~m}$ in LC and in RV at $5 \mathrm{~m}$ (Figure 2). Differences in depth were found within $P R$ (ANOVA, $F=38.69, \mathrm{df}=1, P<0.001)$ and SAR $(F=$ 13.20, $\mathrm{df}=1, P<0.001)$, while LC $(F=2.01, \mathrm{df}=1, P=$ $0.159)$ and $\mathrm{RV}(F=0.0008, \mathrm{df}=1, P<0.997)$ did not exhibit a great vertical changes in abundance. Furthermore, we did not find a strong relationship between depth and mean density of $D$. africanum $(r=0.247, \mathrm{~N}=384, P<0.01)$.

Overall mean size of $D$. africanum during the study was $5.06 \pm 1.01 \mathrm{~cm}$. The maximum average mean size was recorded in $\mathrm{RV}(5.53 \pm 0.92 \mathrm{~cm})$, followed by PR, LC and lastly SAR, with $4.29 \pm 0.68 \mathrm{~cm}$. The spatial variability showed that $R V$ and PR were the two sites with greater mean sizes at some intervals, whereas SAR and LC remained below $6.0 \mathrm{~cm}$ (Figure 3). The classes two and three together represented $94 \%$ of the whole sample, and class 2 alone represented more than $65 \%$ of the individuals collected during the study.

Differences in depth of mean sizes showed that in PR and RV mean sizes increase between 5 and $10 \mathrm{~m}$, whereas in LC and SAR sizes diminished between 10 and $20 \mathrm{~m}$ (Figure 3). The two-way ANOVA performed only at $10 \mathrm{~m}$ found significant spatial and temporal mean sizes (Table 2). All sites exhibited differences $(P<0.001)$ among the others in a post-hoc analysis, whereas temporal differences were not remarkable except between the warm seasons of 2005 and $2006(P=0.095)$, and between the cold seasons of 2006 and $2007(P=0.997)$.

The morphometric analysis of the Aristotle's lantern structure found that the width of the structure decreased in a

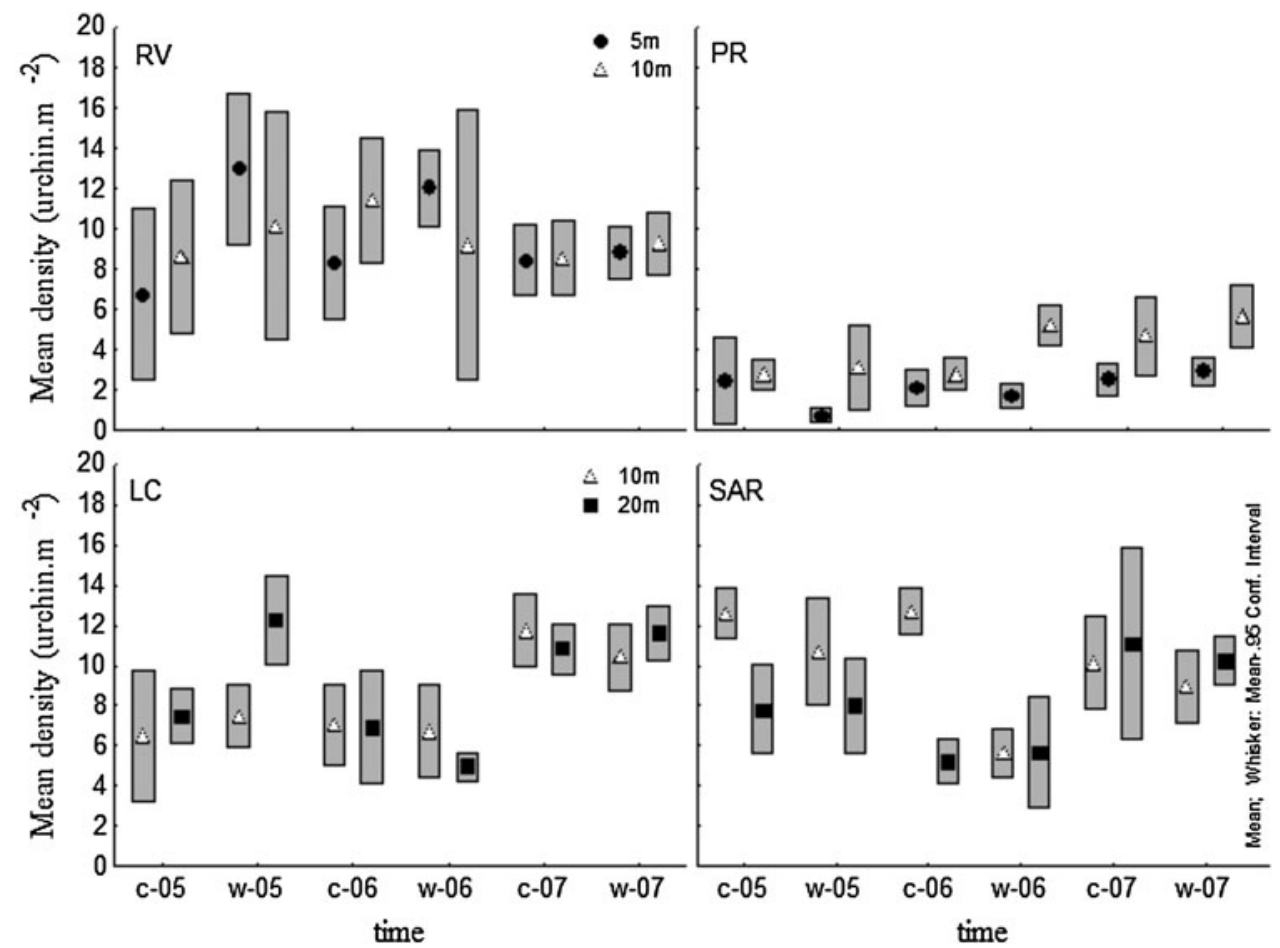

Fig. 2. Spatial and temporal density of Diadema africanum in Gran Canaria from cold season 2005 to winter of 2007 at three depths (5, 10 , and $20 \mathrm{~m})$ at four sites (see Materials and Methods for sites acronyms). The $X$ axis represents time with cold-2005 (c-05), warm-2006 (w-06), etc. Depths are represented by square ( $5 \mathrm{~m}$ ), circle $(10 \mathrm{~m})$, and triangle $(20 \mathrm{~m})$. Bars represent $95 \%$ of confidence interval of the mean. 


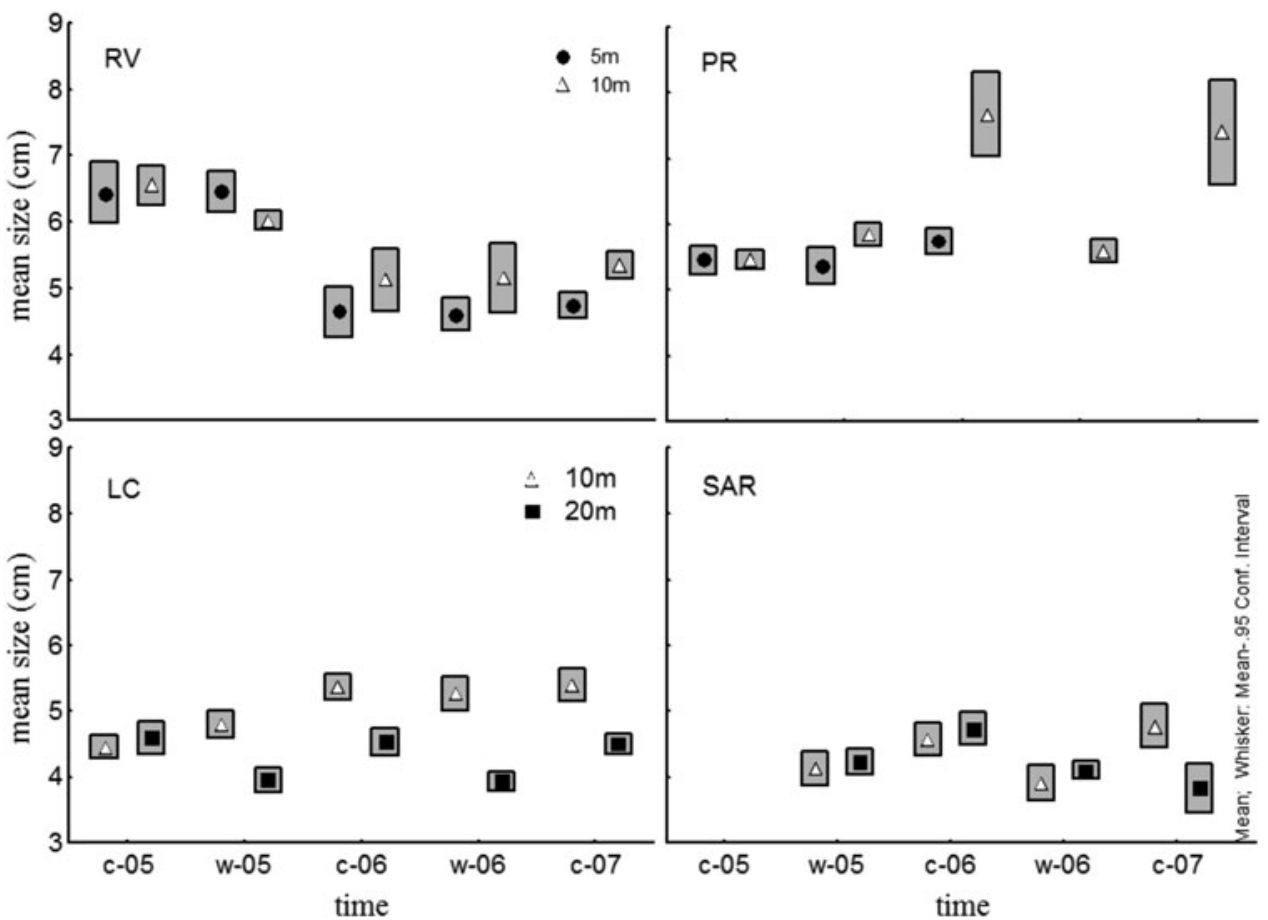

Fig. 3. Seasonal mean size distribution of Diadema africanum at four sites in Gran Canaria. The X axis represents time with cold-2005 (c-05), warm-2006 (w-06), etc. Depths are represented by square $(5 \mathrm{~m})$, circle $(10 \mathrm{~m})$, and triangle $(20 \mathrm{~m})$. Bars represent $95 \%$ of confidence interval of the mean. There are some missing data because not all sites were measured in all seasons. Lack of information (SAR c-05, PR w-06 and c-07 at $10 \mathrm{~m}$ ) represents missing data.

vertical gradient, notably between 10 and $20 \mathrm{~m}(F=12.307$, $d=2, P<0.001)$. A post hoc comparison found a lack of difference only between 5 and $10 \mathrm{~m} \quad(P=0.245)$ (Figure $3 \mathrm{~A}$ ). On the other hand, the width of the lantern was greater at $\mathrm{PR}$ and $\mathrm{RV}$ and lower in LC and SAR (Figure $3 \mathrm{~B}$ ). A one-way ANOVA found spatial differences $(F=8.43, d=3, P<0.001)$, whereas post hoc comparisons did not find differences between either RV and PR or LC and SAR $(P>0.05)$.

\section{DISCUSSION}

The general stability displayed at all sites in abundance confirms the high seasonal stability of $D$. africanum population on Gran Canaria. Temporal stability in abundance of this invertebrate agrees with previous studies conducted throughout the Canary Archipelago (Brito et al., 1984; Bortone et al., 1991; Tuya et al., 2006, 2007; Hernández et al., 2007; Clemente et al., 2010; Hernández et al., 2011). The existence of a depth gradient was notable at least for PR and SAR. This result agrees with other studies conducted in Canary Islands (Tuya et al., 2004b; Hernández et al., 2005, 2007). The hydrodynamic action in intertidal and subtidal environments affects the distribution patterns of marine organisms (Roberts et al., 2006).

The existence of higher densities of D. africanum in deeper areas in PR and SAR could be supported by the negative relationship between depth and wave effect (Roberts et al., 2006). The sea urchin D. africanum is weakly resistant to unidirectional hydrodynamic forces, because its morphology does not allow a large adhesive surface area to attach to the bottom (Tuya et al., 2007). Higher hydrodynamics in shallow areas also may limit $D$. africanum recruitment, according to Tuya et al. (2007), which affects population growth. Nevertheless, the vertical distribution of D. africanum in the Macaronesia Archipelago showed that the species was more abundant in shallow water areas (Entrambasaguas et al., 2008), as occurs with Diadema antillarum in the Caribbean (Hendler et al., 1995).

The vertical Aristotle's lantern results (Figure 4) agreed with other studies that indicate a limited growth of $D$. africanum at greater depths (Levitan, 1988; Garrido, 2003; Hernández et al., 2005, 2007). However, we only found this behaviour in LC, whereas SAR displayed an inverse relationship and PR and RV did not exhibit a clear pattern (Figure 3). The reduction in width of this structure may be a result of food restrictions due to a decrease in vegetation cover and/or lower primary production limited by light intensity (Alves et al., 2001; Lessios et al., 2001a, b). In addition, Levitan (1991) found that Diadema might adjust its body size as a function of available resources, as an adaptive strategy to protect against the harmful effects of increased density.

A limiting factor shaping abundance and size of $D$. africanum are food resources, and in barrens this factor is determinant. Urchin barrens have greater development in deeper zones due to continuous grazing activity, whereas in shallower waters, grazing remains restricted during night-time (Tuya et al., 2004c). It has been demonstrated for sea urchins of temperate zones that recruitment may be favoured under high density conditions, due to higher larval settlement success (Balch et al., 1998; Tuya et al., 2006). However, when densities reached 10 urchin $\mathrm{m}^{-2}$ or higher, sea urchins may collapse benthic production (Tuya et al., 2004b). The existence of a correlation between size and urchin barrens development found here is consistent with other studies (Black et al., 1982; Ebert, 1983; McClanahan (1991); Levitan \& Sewell, 1998; Garrido, 2003). For instance, we found that barrens with less algal cover have higher densities but smaller urchins. 


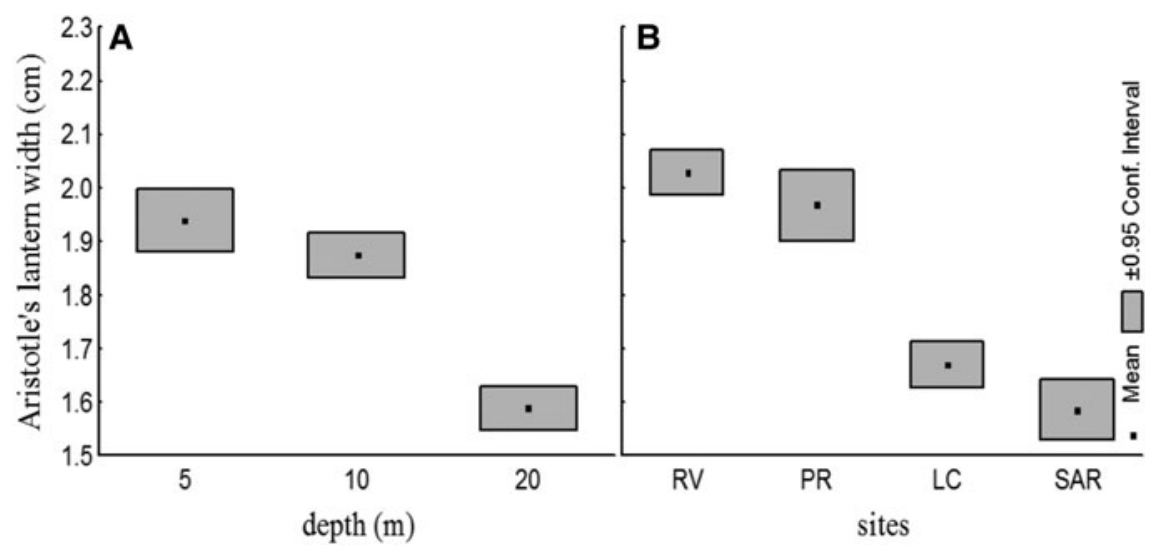

Fig. 4. The Aristotle's lantern width variation on a depth gradient (A) and among the four sites in Gran Canaria (B). Grey colums represent 95\% of confidence interval of the mean.

Further studies on the trophic ecology would provide a better understanding of how D. africanum can persist over long periods with a high reproductive success and seasonal stability, even at the limit of the carrying capacity of the environment. Despite extensive studies on the biological role of this species, there are still some questions as to how this species is dominant and is the key genera on both sides of the Atlantic.

To conclude, population density of $D$. africanum exhibited high temporal stability in Gran Canaria, while changing across a vertical gradient and between sites. The existence of higher densities and smaller sizes in deeper areas explains how the density-size strategy displayed by Diadema sp. (Levitan, 1989 , 1991) accounts for the high stability of the urchin barrens, once developed, remaining as areas of permanent desertification at subtidal depths throughout the Canary Archipelago.

\section{ACKNDWLEDGEMENTS}

We would like to thank the logistic support provided by the Department of Biology, Marine Sciences Faculty, University of Las Palmas de Gran Canaria and the University Foundation. We also want to express our gratitude to the students of scientific diving for supporting fieldworks.

\section{FINANCIAL SUPPDRT}

The first author expresses gratitude to the Mexican National Council for Science and Technology (CONACyT) for a scholarship.

\section{REFERENCES}

Alves F.M.A., Chicharo L.M., Serräo E. and Abreu A.D. (2001) Algal cover and sea urchin spatial distribution at Madeira Island (NE Atlantic). Scientia Marina 65, 383-392.

Alves F.M.A., Chícharo L.M., Serräo E. and Abreu A.D. (2003) Grazing by Diadema antillarum (Philippi) upon algal communities on rocky substrates. Scientia Marina 67, 307-311.

Balch T., Scheibling R.E., Harris L.G., Chester C.M. \& Robinson S.M.C. (1998) Variation in settlement of Strongylocentrotus droebachiensis in the northwest Atlantic: effect of spatial scale and sampling method. In Mooi R. and Telford M. (eds) Echinoderms. Rotterdam: A.A. Balkema, pp. 555-560.

Black R., Johnson M.S. and Trendall J.T. (1982) Relative size of Aristotle's lantern in Echinometra mathaei occurring at different densities. Marine Biology 71, 101-106.

Bortone S.A., Van Tassell J., Brito A., Falcon J.M. and Bundrick C.M. (1991) A visual assessment of the inshore fishes and fishery resources of El Hierro, Canary Islands: a Baseline Survey. Scientia Marina 55, 529-541.

Brito A., Hernández J.C., Falcón J.M., García N., González-Lorenzo G., Gil-Rodríguez M.C., Cruz-Reyes A., Herrera G., Sancho A., Clemente S., Cubero E., Girard D. and Barquín J. (2004) El Erizo de lima (Diadema antillarum) una especie clave en los fondos rocosos litorales de Canarias. Makaronesia 6, 68-86.

Brito T., Cruz E. and Moreno-Pérez J.M. (1984) Fauna marina de las Islas Canarias. In Bacallado J.J. (ed.) Fauna marina y terrestre del Archipiélago Canario. Edirca: Las Palmas de Gran Canaria, pp. 42-65.

Cabanillas-Terán N. (2009) Ecología y estatus trófico del erizo de mar Diadema antillarum (Philippi, 1845) en los fondos rocosos de las Islas Canarias (Gran Canaria, España). PhD thesis. Universidad de Las Palmas de Gran Canaria, Spain, available at: http://hdl.handle. net/10553/2589 (accessed 8 August 2014).

Clemente S., Hernández J.C., Rodríguez A. and Brito A. (2010) Identifying keystone predators and the importance of preserving functional diversity in sublittoral rocky bottoms. Marine Ecology Progress Series 413, 55-67.

Dayton P.K., Currie V., Gerrodette T., Keller B.D., Rosenthal R. and Tresca D.V. (1984) Patch dynamics and stability of some California kelp. Ecological Monographs 54, 254-289.

Ebert T.A. (1980) Relative growth of sea urchin jaws: an example of plastic resource allocation. Bulletin of Marine Science 30, 467-474.

Ebert T.A. (1983) Recruitment in echinoderms. In Jangoux M. and Lawrence J.M. (eds) Echinoderm studies. Rotterdam: A.A. Balkema, pp. $169-203$.

Entrambasaguas L., Pérez-Ruzafa A., García-Charton J.A., Stobart B. and Bacallado J.J. (2008) Abundance, spatial distribution and habitat relationships of echinoderms in the Cabo Verde Archipelago (eastern Atlantic). Marine and Freshwater Research 59, 477-488.

García-Sanz S., Navarro P.G. and Tuya F. (2014) Contrasting recruitment seasonality of sea urchin species in Gran Canaria, Canary Islands (eastern Atlantic). Mediterranean Marine Science 15, 475-481. 
Garrido M.J. (2003) Contribución al conocimiento de Diadema antillarum Philippi 1845, en Canarias. PhD thesis. Universidad de Las Palmas de Gran Canaria, Spain.

Hagen N.T. and Mann K.H. (1992) Functional response of the predators american lobster Homarus americanus (Milne-Edwards) and Atlantic wolffish Anarhichas lupus (L.) to increasing numbers of the green sea urchin Strongylocentrotus droebachiensis (Müller). Journal of Marine Experimental Biology and Ecology 159, 89-112.

Hendler G., Miller J.E., Pawson D.L. and Kier P.M. (1995) Sea stars, sea urchins, and allies. Echinoderms of Florida and the Caribbean. Washington, DC: Smithsonian Institution Press. Washington, DC and London, 390 pp.

Hernández J.C., Clemente S. and Brito A. (2011) Effects of seasonality on the reproductive cycle of Diadema aff. antillarum in two contrasting habitats: implications for the establishment of a sea urchin fishery. Marine Biology 158, 2603-2615.

Hernández J.C., Clemente S., Brito A., Falcon J.M., García N. and Barquin J. (2005) Estado de las Poblaciones de Diadema antillarum (Echinoidea: Diadematidae) y del recubrimiento de macroalgas en las Reservas Marinas de Canarias: Patrones de distribución espacial. Vieraea $33,367-383$.

Hernández J.C., Clemente S., Sangil C. and Brito A. (2007) Actual status of Diadema aff. antillarum populations and macroalgal cover in the Marine Protected Areas comparing to a Highly Fished Area (Canary Islands-Eastern Atlantic Ocean). Aquatic Conservation: Marine and Freshwater Ecosystems 18, 1091-1108.

Hernández J.C., Clemente S., Sangil C. and Brito A. (2008) The key role of the sea urchin Diadema aff. antillarum in controlling macroalgae assemblages throughout the Canary Islands (eastern subtropical Atlantic): an spatio-temporal approach. Marine Environmental Research 66, 259-270.

Hughes T.P. (1994) Catastrophes, phase shifts and large-scale degradation of a Caribbean coral reef. Science 265, 1547-1551.

Hyman L.H. (1955) The invertebrates: Echinodermata (Volume 4). New York: McGraw-Hill.

Lawrence J.M. (1975) On the relationships between marine plants and sea urchins. Oceanography and Marine Biology: an Annual Review 13, $213-286$

Lessios H.A. (2013) 'Natural' population density fluctuations of echinoids Do they help predict the future? In Fernández-Palacios J.M., de Nascimento L., Hernández J.C., Clemente S., González A. and DíazGonzález J.P. (eds) Climate change perspectives from the Atlantic: past, present and future. Servicios de Publicaciones, Universidad de La Laguna, pp. 341-359.

Lessios H.A., Garrido M.J. and Kessing B.D. (2001a) Demographic history of Diadema antillarum, a keystone herbivore on Caribbean reefs. Proceedings of the Royal Society of London Series B-Biological Sciences 268, 2347-2353.

Lessios H.A., Kessing B.D. and Pearse J.S. (2001b) Population structure and speciation in tropical seas: global phylogeography of the sea urchin Diadema. Evolution 55, 955-975.

Levitan D.R. (1988) Density-dependent size regulation and negative growth in the sea urchin Diadema antillarum Philippi. Oecologia 76 $627-629$.

Levitan D.R. (1989) Density-dependent size regulation in Diadema antillarum: effects on fecundity and survivorship. Ecology 70, 1414-1424.

Levitan D.R. (1991) Skeletal changes in the test and jaws of the sea urchin Diadema antillarum when food-limited. Marine Biology 106, 431435 .

Levitan D.R. and Sewell M.A. (1998) Male abundance and fertilization success in free-spawning marine invertebrates: review of the evidence and fisheries implications. In Jamieson G.S. and Campbell A. (eds) Proceedings of the North Pacific Symposium on Invertebrate Stock Assessment and Management. Volume 125. Canadian Special Publication in Fisheries and Aquatic Science, National Research Press, Canada, pp. 159-164.

McClanahan T.R. (1994) Kenyan coral reef lagoon fish: associations with reef management, complexity and sea urchins. Coral Reefs 13 , $231-241$.

McClanahan T.R. and Curtis J.D. (1991) Population regulation of the rock-boring sea urchin Echinometra mathaei de Blainville. Journal of Experimental Marine Biology and Ecology 147, 121-146.

McClanahan T.R., Kamukuru A.T., Muthiga N.A., Yebio M.G. and Obura D. (1996) Effect of sea urchin reductions on algae, coral, and fish populations. Conservation Biology 10, 136-154.

Menge B.A. (1992) Community regulation: under what conditions are bottom-up factors important on rocky shores? Ecology 73, 755-765.

Randall J.E., Schroeder R.E. and Starck W.A. (1964) Notes on the biology of the echinoid Diadema antillarum. Caribbean Journal of Science 4, 421-433.

R Core Team (2013) R: a language and environment for statistical computing. Vienna: R Foundation for statistical computing. Available at: http://www.R-project.org/ (accessed 8 August 2014).

Roberts D.E., Cummins S.P., Davis A.R. and Chapman M.G. (2006) Structure and dynamics of sponge-dominated assemblages on exposed and sheltered temperate reefs. Marine Ecology Progress Series 321, 19-30.

Rodríguez A., Hernández J.C., Clemente S. and Coppard S.E. (2013) A new species of Diadema (Echinodermata: Echinoidea: Diadematidae) from the eastern Atlantic Ocean and a neotype designation of Diadema antillarum (Philippi, 1845). Zootaxa 3636, 144-170.

Sala E. and Ballesteros E. (1997) Partitioning of space and food resources by three fish of the genus Diplodus (Sparidae) in a Mediterranean rocky infralittoral ecosystem. Marine Ecology Progress Series 152, $273-283$.

Sala E., Boudouresque C.F. and Harmelin-Vivien M. (1998) Fishing, trophic cascades and the structure of algal assemblages: evaluation of an old but untested paradigm. Oikos 82, 425-439.

Sala E. and Zabala M. (1996) Fish predation and the structure of sea urchin Paracentrotus lividus populations in the NW Mediterranean. Marine Ecology Progress Series 140, 71-81.

Sammarco P.W. (1982) Echinoid grazing as a structuring force in coral communities: whole reef manipulations. Journal of Experimental Marine Biology and Ecology 61, 31-55

Tuya F., Boyra A., Sánchez-Jerez P., Barbera C. and Haroun R.J. (2004a) Relationships between rocky-reef fish assemblages, the sea urchin Diadema antillarum and macroalgae throughout the Canarian Archipelago. Marine Ecology Progress Series 278, 157-169.

Tuya F., Boyra A., Sánchez-Jerez P., Barbera C. and Haroun R.J. (2004b) Can one species determine the structure of the benthic community on a temperate rocky reef? The case of the long-spined sea-urchin Diadema antillarum (Echinodermata: Echinoidea) in the eastern Atlantic. Hydrobiologia 519, 211-214.

Tuya F., Cisneros-Aguirre J., Ortega-Borges L. and Haroun R.J. (2007) Bathymetric segregation of sea urchins on reefs of the Canarian Archipelago: role of flow-induced forces. Estuarine, Coastal Shelf Science $73,481-488$.

Tuya F., Martín J.A. and Luque A. (2004c) Patterns of nocturnal movement of the long-spined sea urchin Diadema antillarum (Phillipi) in Gran Canaria (the Canary Islands, Central East Atlantic Ocean). Helgoland Marine Research 58, 26-31. 
Tuya F., Ortega-Borges L., Del Rosario-Pinilla A.B. and Haroun R.J. (2006) Spatio-temporal variability in a key herbivore, the long-spined black sea urchin (Diadema antillarum, Echinodermata: Echinoidea) in the Canary Islands. Journal of the Marine Biological Association of the United Kingdom 86, 791-797.

Tuya F., Sánchez-Jerez P. and Haroun R.J. (2005) Influence of fishing and functional group of algae on sea urchin control of algal communities in the eastern Atlantic. Marine Ecology Progress Series 287, 255-260.

Uthicke S., Schaffelke B. and Byrne M. (2009) A boom-bust phylum? Ecological and evolutionary consequences of density variations in echinoderms. Ecological Monographs 79, 3-24.

Vanderklift M.A. and Kendrick G.A. (2004) Variation in abundances of herbivorous invertebrates in temperate subtidal rocky reef habitats. Marine and Freshwater Research 55, 93-103.
Young C.M. and Chia F.S. (1982) Factors controlling spatial distribution of the sea cucumber Psolus chitonoides: settling and post-settling behavior. Marine Biology 69, 195-205.

and

Zar J.H. (2010) Biostatistical analysis. 5 th edition. Upper Saddle River, NJ: Prentice-Hall.

\section{Correspondence should be addressed to:}

N. Cabanillas-Terán

Departamento Central de Investigación, Universidad Laica Eloy Alfaro de Manabí, Ciudadela Universitaria, Vía San Mateo, Manta, Manabí, Ecuador emails: nanchamex@gmail.com/nancy.cabanillas@uleam.edu.ec 